\title{
The Effectiveness of Historical Teaching Material Based on Problem Based Learning (PBL) to Improve the Senior High School Students Ability of Historical Explanation
}

\author{
Tyas Fernanda*; Leo Agung S; Sariyatun \\ Sebelas Maret University, Indonesia \\ Email: Fernandatyas21@gmail.com
}

http://dx.doi.org/10.18415/ijmmu.v5i3.245

\begin{abstract}
Historical teaching material is one of the medias in the form of printed material. Historical teaching material is important used in historical learning because historical teaching material contains some historical facts which can help to improve the students' ability of historical explanation. The results of the research conducted shown that the use of historical teaching material is very minimum as well as the use of historical teaching material which contains local history. The implementation of historical teaching material uses the cooperative learning model namely problem based learning (PBL). Based on the existed theories, the cooperative learning can stimulate the ability owned by students including the ability to think critically and construct the existed knowledge of historical facts. Based on the things, it is needed to develop a historical teaching material which contains local history material to improve the Senior High School students' ability of historical explanation. The method used in this research is quasi experiment with two classes divided into one controlled class and one experimental class. This research took the students of XI grade in SMA Negeri 1 Lawang Kidul the Regency of Muara Enim as the sample. This research tested the effectiveness of students' ability of historical explanation and obtained the following calculation results: the post-test average of experimental class is 74,17 and the post-test average of controlled class is 65,67 and it continued with the results of T-test with a score of 4,510 and the significance average of $0,000<0,025$.
\end{abstract}

Keywords: Teaching material; Problem based learning; Historical explanation

\section{Introduction}

Learning is a permanent impact on attitude, knowledge and the ability of thinking obtained from the own experiences (Santrock., 2007: 266). Learning is an activity which organizes or arranges an environment well and links it with students, in order to make interaction process between educators and learners. Learning is involved in the reflection and the use of human's memory to process the obtained information. The role of memory is much needed for reflection process in forming both behavior and attitude got from the learning process. Learning more emphasizes on educator for the whole process of delivering material or information to learners. Educators must have the ability to design a good learning process in order to reach the purposes of the learning. 
The efforts to create a meaningful environment of learning still become the task for every educational practitioner. The educational development related to curriculum, method, media of learning material, the quality of educator, and so on is required to advance the education in Indonesia. For example, there are many educators who have low quality and tend to be reluctant in creating or developing material or media in learning. Besides, educator as the spearhead in a learning is demanded to be able to develop the potential within the students' self. It should be that educator has an ability to master and describe the subjects, plan and prepare the daily materials, control and evaluate students' activity (Sadirman., 2001: 143).

The result of observation done in one of state senior high schools, there were some educators especially the teachers of history who used lecturing method without using model or additional media in the learning process. Educator in delivering material only used the media of students' worksheets (LKS, handout and less utilization maximally of learning facilities provided in classroom. In teaching, educator is conventional which is learner focused on educator. As the results, the learning activity tends to be boring and makes students feel sleepy and less motivated. Along with the development of science and educational technology, learning must not be conservative. Education can be done through various media such as radio, television, internet, and digital comic.

One of the media used by educator in historical learning is the teaching material which contains the material of local history. According to Dick \& Carey (2009: 230), stated that teaching material consists of written material, media material or material facilitated by an educator which can be used by learners to reach the purposes of learning. It includes the material for main purpose and final purpose as well as all materials to increase the memory and transfer. Teaching material refers to every existed material combined as well as the material developed specifically for certain purposes. The material includes information which will be used by learners to lead their development through learning. The historical learning will be truly useful if leaners are able to give historical explanation.

The learning theory of constructivism, learner is led to do a historical research. The research will be described in the form of writing about historical events either for national or local scope. So far, the existed historical resources are just limited to the national scope, while for the historical writing in local scope is still deficient. It causes the lack of students' historical understanding for local level. It has been the task for educators to excavate the potential especially historical understanding within students' self. However, if educators still use conventional methods in historical learning so it will be impossible to expect a historical explanation deeper from learners especially in the local context.

It is unfortunate if history is ignored and learners at school are just given historical explanations in national scope. Meanwhile every region has a locality of history that is interesting to be understood. The unbalanced of delivering material between national and local scope in historical learning cause the lack of local history understanding in every region. One of the ways to make the students' ability of historical understanding and historical explanation better is by using the material containing local material. Based on the explanation above, the researcher assumed that it needs to develop a historical material in order to create more effective learning with the purposes to improve the students' ability of historical explanation.

\section{Methodology}

The effectiveness research of this historical material used experimental quasi method. The purposes of conducting the research are to test the teaching material in improving the Senior High School students' ability of historical explanation in Lawang Kidul. This research used the development method of Research and Development (R\& D) which refers to the development design of ADDIE which has five 
stages of analysis, design, development, implementation, and evaluation (Januszewski \& Molenda., 2008: 107). The objects of this research are the Senior High School students in Lawang Kidul. The researcher used two classes as the objects of research. One class was as controlled class and the other class was experimental class. The subjects of this research are the students Senior High School students of XI grade in one of the Senior High Schools in Lawang Kidul with the number of experimental class is 30 students.

This research will do different treatment between experimental class (XI of Social Science C) and controlled class (XI of Social Science B). The experimental class will be applied the learning design of historical teaching by using the learning model of problem based learning, while the controlled class will be applied the model of conventional learning. Three stages that will be conducted in this research are (1) the beginning stage, (2) the implementation stage, (3) the final stage. This research also uses the learning tool (RPP). The data required from this research is the average score of students' ability of historical explanation. The high-low of students' ability in explaining is measured by using the method of test and instrument which are developed for the test and adapted with the cognitive ability of students. The form of test used is the test of objective multiple-choice with the correct answer got 1 and incorrect answer got 0 .

\section{Result and Discussion 1. Teaching Material}

Teaching material is learning material which greatly covers knowledge, skill, and attitude which must be learned by students in order to reach the determined standard of competence. In detail within teaching material, there are kinds of learning materials which consist of knowledge, skill and attitude as well as value (Hamid., 1997: 212). Meanwhile according to Sudjana (2009: 67), teaching material is a content given to learners during the learning process. Through teaching material, students are led to the purposes of the learning. In other words, the purposes of learning that will be reached are colored and formed by teaching material. Teaching material in essence is the content of lesson or subject given to learners with the used curriculum.

The explanation of the concept above can be concluded that teaching material is an information, tool, text, and any kinds of teaching materials both written materials and unwritten materials which will be used by educator to help them in doing the learning activities in class in order to create a conducive atmosphere of the class. With the other word, it helps learners receive the learning materials easily and it helps educators to plan and analyze the implementation of learning.

The purposes of the material arrangement are to activate and support the learning process in accordance with the school's needs, learners' living space, and learners' needs. In addition, the material arrangement can help educator in the learning process and facilitate the material displaying which will be given to learners. Daryanto dan Dwicahyono (2014: 172), revealed the benefits of teaching material as the following:

\section{a. The Benefits for Educator}

1) It is obtained teaching material which is accordance with the demanding of curriculum and the needs of learners.

2) It does not depend on textbook anymore which hardly to get sometimes.

3) It enriches material because it is developed by using any references. 
4) It adds knowledge and experiences of educator in writing teaching materials.

5) It helps an effective communication of learning between educators and learners because learners will trust more to the educators.

6) It adds credit numbers of DUPAK (the proposal lists of proposed credit numbers) if it is collected into a book and published.

\section{b. The Benefits for Learner}

1) The learning activity becomes more interesting.

2) It becomes a chance to learn independently and reduces the dependence of educator's presence.

3) It gets easiness in learning every competence that must be mastered.

Richards (1995: 275) categorized three sets of teaching materials: 1) printed material such as textbook, exercise book, worksheet; 2) non-printed material such as cassette (audio material), video or material based on computer; 3 ) authentic and created teaching material, i.e. teaching material of which the sources related to the real life both in the form of printed and non-printed material such as the materials which are accessed by educator or learner, magazine, newspaper, brochure and internet resource. While according to Opara and Oguzor (2011:67) stated that teaching material is classified into seven categories namely 1) printed material; 2) picture; 3) a projected still image; 4) moving image; 5) audio material; 6) three dimensions; 7) the material of computer program.

It needs to be known that the development of teaching material is based on the syllable which is firstly arranged, then developed in the form of teaching material. The development of teaching material should consider four aspects, the followings are: 1) academic aspect, 2) social aspect, 3) recreation aspect, 4) personal development aspect. The development of systematical teaching material begins from the process of design and development or using the existed teaching material, to the experiment of teaching material, the knowledge towards the factors which influence on the quality of result need to be considered in developing teaching material and the procedure of systematical teaching material (Romiszowki., 1986: 22).

The teaching material must be developed in accordance with the development principle of teaching material. The signs which must be obeyed in arranging teaching material based on Chomsin S.W. and Jasmadi (2008: 42) are:

1) Teaching material must be adjusted with learners in the learning process,

2) Teaching material is expected able to do change learners' attitude,

3) The developed teaching material must be adjusted with needs and self's characteristic,

4) The program of teaching-learning will be on going,

5) There are the purposes of specific learning activity in the teaching material, 
6) Teaching material should contain learning material in detail both for activities and exercises in order to support the purposes' achievement,

7) There is evaluation as the feedbacks and tools to measure the level of learners' achievement

Based on the principle of teaching materials development above, can be concluded the development of teaching materials in schools need to consider the students characteristic and students needs according to the curriculum, which requires more participation and students activities in learning. The development of teaching materials in the form of historical textbooks in this local context is expected to be used as learning material. it is useful for students to understand and explore history at the local level.

\section{Learning Model of Problem Based Learning}

Cooperative learning is a learning model that prioritizes cooperation to achieve learning objectives. cooperative learning is in the learning form by students learning and working ways in small groups collaboratively (Majid., 2008: 174). Anita Lie mentions cooperative learning as gotong-royong. This learning system provides students oportunities to work with other students in structured tasks. Moreover, he thinks cooperative learning only works when a group or a team which students work directed to achieve the goals that have been determined (Isjoni., 2007: 16).

Learning model is a framework that becomes a frame in the whole learning process. There are several types of learning models that have been presented in the above discussion. However, in this research the model used is problem -based learning. According to Barrow (Huda., 2014: 71) the problembased learning model is the learning gained through the process towards understanding the problem resolution. Problem-based learning model incorporates various disciplines sciences in solving problems (Anitah., 2009: 70). From that quote, we can take a sense that the problem-based learning model is learning design that gives the students direction to solve a problem. Problems will be faced by learners is a problem related to learning materials and real conditions in the students environment who are deliberately designed by teachers. The purpose to designed the problem is making students to have skills in giving wise solutions by some aspects accordance to the problems background.

Problem based learning demands students to active do investigating in problem solving and teachers play role as facilitator and mentor. learning will be formed high level thought skills and improve students to think critically (Abdullah., 2014: 127). Critically thought process starts when students faced to the real problems in their environment. Meanwhile for solve the problems, students are directed to understand the material learned or experience as the resolution basic. In the profer resolution finding process should be a mentoring from teachers or workteam, because during resolution finding process of course, there is students ideas as problem solving. When students need help from others because the limited the students start to develop their own knowledge and thought critically. Students should understand various aspects to decided the profer resolution.

There are fives steps learning in PBL process, as follows: Students orientation in problems, in this step teacher submits problems to students so students can find the ideas to solve the problems. (2) Organize students in learning, teachers make condition for students to learn and find problem solving (3) in the third steps teachers are directing students to decide the profer possibility in problems (4) develop and present work result, students arrange discussion results and make a presentation so this activity will be seen temporary result from students understanding about learning material (5) Analyze and evaluate 
temporary problem solving process. In this last step, teacher and students anlyze and evaluate problem soving results so the students understanding will be formed.

Learning steps in Problem Based Learning will applicate in teaching materials of colonial government system in Palembang residency and will be used in teaching materials implementation in learning process. PBL is chossen because this model will be directing students to develop students choosen cognitive because tis model will direct students to develop students cognitive. Where the problem faced by students are related to real life involve the students experiences, meanwhile for finding the proper solving students should have social ability to understand how to implementing the giving solutions. It is similiar to Piaget (Wadsworth., 1984: 29). There are four factors that influence kognitif development a person, they are experiences, maturity, social transmition equilbiration or internal balance.

The using of problem based learning model in historical material of Dutch Colonial goverment system in Palembang Residency are hoped to help the effectivity of directing students thought critically in giving opinion the historical facts. Therefore, it can produce the good historical explanation. Through problem baec learning, historical facts in the historical material of the Dutch colonial goverment system in Palembang Residency can reconstucted by students.

\section{Explanation}

Based on Daliman (2012: 67) Explanatiom simple historical should be fullfilled some arranging questions in 5W 1H What (apa), Who (siapa), Where (di mana), When (kapan), Why (mengapa) dan How (bagaimana). In explaining a historical event need to explain what the event, who the people in the event, where it happens, when it happens, the event background, and how it happens. Kuntowijoyo (2008: 10) reveals historical explanation can be formulated into three main holds, they are: (1) historical explanation is hermeneutik and verstehen, intepreting and understanding; (2) Historical explaination is the expalanation about the longer time; and (3) historical explaination is single event. Therefore, every historical events should be contemplated and understang the thinking, soul and values. The explainantion or explanation of the historic based on the opinion, every moment has the uniqueness and individuality so the moment can be analyzed and reducted. Every moment only needs tracked again to the previous moment (Kartodirjo., 1993: 233). Therefore, it can be said that historical explanation is a proccess that showing the certain moment connected to another moments through profer general statements.

As science, the historical is bounded on scientific research procedure. Scientific research is source and effort of science development. Historical is also bounded in reasoning which bases itself on facts. Facts are data that have been tested truth through the test (criticism) source. These facts are the mainstay of historical truth. To obtain historical truth, much depends on the willingness of historians to examine and examine historical sources thoroughly and correctly, so to be able to reveal history with objective (or close to objective). The final result is the correspondence between the historians understanding (historiography) and the facts.

Therefore, historical explanation is one important aspect in history. This are used for developp, analyze, and explain the relations between statements of phenomenons. In historical science as a deal of historian calls causations and connections that are used by historian when they shyntesize the facts. Historical explaination accordance to Kuntowijoyo (2008: 2-10) is a shytesis to historical facts. 


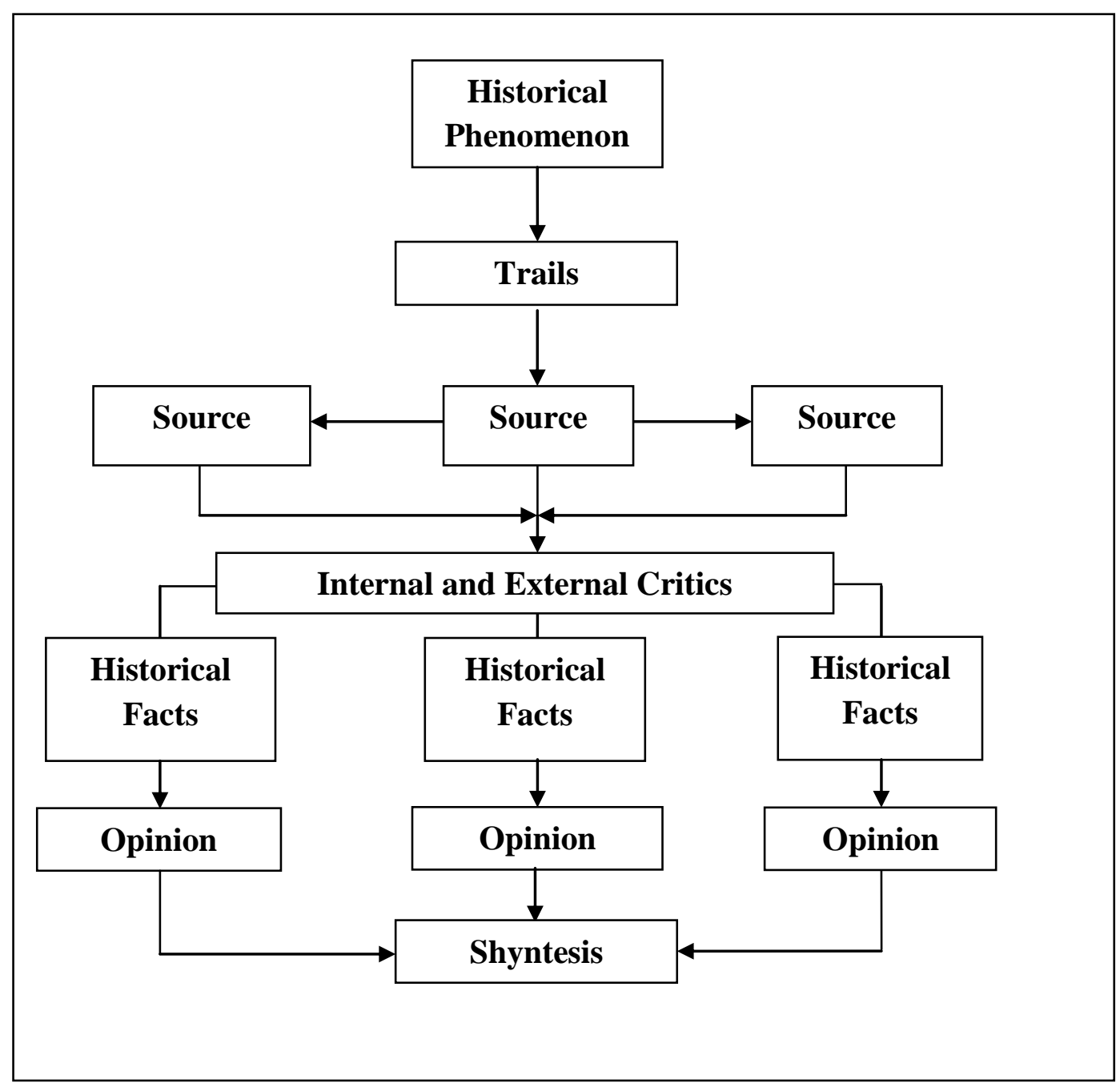

Fig. 1 Historical explanation plots by Kuntowijoyo

\section{The Effectiveness of Historical Material of Dutch Colonial Goverment System in Palembang Residency Based on Problem Based Learning}

The effectivity of historical material of Dutch colonial goverment system in Palembang Residency based on Problem Based Learning can be known through comparison results of pretest and posttest control class and experimental class. The effectiveness test of this product has been done to class of XI IPS C as experiment class and Class of XI IPS B as control class at SMA Negri 1 Lawang Kidul. The given tests are cognitive questions that related to the the historical explanation ability indicator. The test results are counted by SPPS 23.

The purpose of historical material implementation can improve students's historical explanation ability. Historical explanation plays very important role in historical metodhology, this causes the historical explanation is the continue of historical facts intrepetation. The good historical explanation in students can be hoped to understand, intepret and understand the values from historical events in order to historical construction not cronic but diacronic. Historical explanation rules are harmonistic, generalitation, periodation, narative historical, multi interpretation. 
Before the effectiveness test, $\mathrm{T}$ test results obtained value of 4.510 with a significance level of $0.000<0.025$ then Ho is rejected, meaning that the average between the experiment class and control class after treatment are not the same. The above data shows a positive and significant improvement in the class that uses the historical material of the Dutch colonial government system in Palembang Residency based on PBL. For conclusion the results of the data obtained is developed historical teaching material has to be effective to improve the students's historical explanation when used in learning.

This study is relevant to the research undertaken by Nancy and Mustaji (2013, 1-15) in a kwangsan journal entitled the development of instructional materials with the ADDIE model for mathematics subjects. The preliminary data of the research were pretest result of experiment class and control class show that $t$ test value was 0.073 , while $t$ test value was 2,069 so that $t$-test value was smaller than t-table value. The conclusion of the pretest value is that no difference in understanding between the control class and the experiment class. Result of posttest data seen from t test there is difference between posttest grade experiment class and posttest of control class. The experiment class is treated by using teaching materials and has a greater posttest value than the control class posttest that does not use teaching materials. The result of the posttest $t$ test shows the value of $t$-test is 7.397 , while the t-test value is 2.069 , which means the value of $\mathrm{t}$-count is greater than the $\mathrm{t}$-table value. The conclusion, the teaching materials used can increase the student achievement.Herman (2013, 178-191) in the Vocational journal with the title is influence of problem based learning on learning results in terms of study motivation of students at SMK. The result of this research is, the students learning results are taught by the PBL model is higher compared to the students result are taught by the model of demonstration learning. Students learning results in practice are also the case. Students who are taught by the PBL model have a higher value compared to the students learning results that are taught in the conventional way. the problem-based learning model is superior compared to conventional and demonstration model learning.

Another research was conducted by Rita and Brenda (2017) in the Interdisciplinary journal of problem-based learning volume 11 issue 2. This research entitled Problem-based learning pedagogy fosters students critical thinking about writing. The results of this research indicate that students have the ability of critical thinking abaout writing better by using PBL. Sstudents have been able to analyze who they wrote and for what purpose they wrote it. Students are also required to work together in this PBL model so between group members should help each other in completing their tasks. Therefore, it can be concluded that problem based learning model is very effective if applied in learning, especially to improve the critical thinking of students in making writing.

\section{Conclusion}

The application of historical teaching materials to improve the students' historical explanation has gone well. Based on test result of difference equality test, test of increase and test of effectiveness of historical explanation ability of students are found difference of t test result of historical explanation, 1) equality of $t$ test obtained value equal to -541 with significance level equal to 0,590 bigger than 0,05 $(0,590>0,05), 2)$ increase is known that $\mathrm{t}$-count <t-table, ie $-9.009<-2,045$, while significance value $<0.05$, that is $0.00<0.05,3) \mathrm{t}$ test obtained value equal to 4,510 with significance level $0,00<0,025$.

Based on the results of effectiveness test that has been done. there is a difference in the increase of historical explanation ability in the experiment class, class XI IPS C is using the historical material of Dutch colonial government system in Palembang Residency accompanied by PBL learning model in its application. Besides the control class, class XI IPS B which only uses textbooks. The conclusion after the treatment is given, the two classes have different levels of historical explanation capabilities. Classes using historical materials of the Dutch colonial government system in Palembang Residency have a better level of historical explanation ability compared to classes that do not use teaching materials. 


\section{References}

Abdullah, Sani Ridwan. (2014). Pembelajaran Saintifik Untuk Kurikulum 2013. Jakarta: Bumi Aksara

A.M. Sardiman. (2001). Inovasi dan Motivasi Belajar Mengajar. Jakarta: Raja Grafindo Persada

Anitah, Sri. (2009). Media pembelajaran. Surakarta: UNS Press.

Bekti, Wulandari dan Herman Dwi C. (2013). Pengaruh Problem Based Learning Terhadap Hasil Belajar Ditinjau dari Motivasi Belajar PLC di SMK. Jurnal Pendidikan Vokasi, 3(2): 178-191.

Chomsin S. Widodo dan Jasmadi. (2008). Panduan Menyusun Bahan Ajar Berbasis Kompetensi. Jakarta: PT Elek Media Komputindo.

Daliman. (2012). Metode Penelitian Sejarah. Yogyakarta: Ombak.

Daryanto, \& Dwicahyono, A. (2014). Pengembangan Perangkat Pembelajaran (Silabus, RPP, PHB Bahan Ajar). Yogyakarta: Gava Media.

Dick, W., Carey, L., dan Carey, J.O. (2009). The Systematic Design of Instruction. New Jersey: Pearson.

Huda M. (2014). Model-model Pengajaran dan Pembelajaran.Yogyakarta: Pustaka Pelajar.

Isjoni. (2007). Cooperative Learning. Bandung: Alfabeta.

Januszewski danMolenda. (2008). Instruction Technology and Media for Learning. New Jersey: Prentice hall.

John W, Santrock. (2007). Perkembangan Anak. Jilid 1 Edisi Kesebelas. Jakarta: PT. Erlangga.

Kartodirjo, Sartono. (1993). Pendekatan Ilmu Sosial dalam Metedologi Sejarah. Jakarta: Gramedia

Kuntowijoyo. (2008). Penjelasan Sejarah (Historical Explanation). Yogyakarta: Tiara Wacana.

Majid, Abdul. (2008). Perencanaan Pembelajaran: Mengembangkan Kompetensi Guru. Jakarta: PT. Rosda Karya.

Nancy, Angko dan Mustaji. (2013). Pengembangan Bahan Ajar dengan Model Addie untuk Mata Pelajaran Matematika Kelas 5 SDS Mawar Sharon Surabaya.. Jurnal Kwangsan, 1(1): 1-15.

Opara, Jacinta and Oguzor, Nkasiobi S. (2011). Instructional Technologies and School Curriculum in Nigeria: Innovations and Challenges. Perspectives of Innovations, Economics \& Business, 7(1), 2011. ISSN 1804-0519.

Richards, J.C. (1995). The Context of Language Teaching. Cambridge University Press.

Rita Kumar dan Brenda Refael. (2017). Problem Based Learning Pedagogy Fosters Students Critical Thinking About Writing. Interdisciplinary Journal of Problem-Based Learning, 11(2), Article 1.

Romiszowski. (1986). Developing Auto Instructional Materials. Philedelphia: Nicolas Publishing. 
Subakti, S. (2010). Paradigma Pembelajaran Sejarah Berbasis Konstruktivisme. Jurnal Paradigma Pembelajaran Sejarah. Universitas Sanata Dharma Yogyakarta. SPPS, Vol. 24.

Sudjana, Nana. (2009). Dasar-dasar Proses Belajar Mengajar. Bandung: SinarBaru Algensindo.

Wadsworth, Barry J. (1984). Piaget's Theory of Cognitive and Affective Development. New York: Longman Inc.

\section{Copyrights}

Copyright for this article is retained by the author(s), with first publication rights granted to the journal.

This is an open-access article distributed under the terms and conditions of the Creative Commons Attribution license (http://creativecommons.org/licenses/by/4.0/). 